\title{
AZ ADATKEZELÉSI JOGALAPOK ALKALMAZHATÓSÁGÁVAL KAPCSOLATBAN BEKÖVETKEZETT VÁLTOZÁSOK A GDPR HATÁLYBA LÉPÉSE ÓTA
}

Dr. Kollár Gergö

PhD ballgató, PTE Allam- és Jogtudományi Doktori Iskola

A szerző" kutatási terïlete: Az adatalapú ü̊leti tevékenységek személyiségvédelemre gyakorolt hatásai, különös tekintettel azok adatvédelmi jogi vonatkozásaira

A szerzóo elérbetösége: kollar.gergo@pte.ajk.hu

\section{DOI: $10.47272 / \mathrm{KIKPhD.2021.1.2}$}

\section{ÖSSZEFOGLALÓ}

Az Általános Adatvédelmi Rendelet ${ }^{1}$ (továbbiakban: Rendelet) 2016-os hatályba lépése - pontosabban 2018-as alkalmazandóvá válása - óta a jogalapok kibővült rendszere számos változást idézett elő a személyes adatok kezelésének jogszerüségi feltételeiről kialakított gondolkodásmódban.

A korábbi nagyrészt két jogalappal múködő (dichotóm) rendszerhez képest jelenleg hat jogalap közül választhat az adatkezelő, ami minden előnye mellett, idôról időre zavart okoz az adatkezelés résztvevőiben.

\section{KULCSSZAVAK}

Adatvédelem, jogalapok, GDPR.

\section{Bevezetés}

A jogalapválasztás izgalmas új rendszerének vizsgálatára kerül sor ebben a tanulmányban, annak érdekében, hogy a megváltozott jogszabályi környezet gyakorlati szempontból legjelentősebb módosításait áttekinthessük. Ehhez a tanulmány során megvizsgálom a Rendelet fontosabb jellemzőit és úításait, különös tekintettel 6. cikkére, valamint végig követem a jogalapválasztás elméleti és gyakorlati körülményeit, továbbá egy általam lehetségesnek ítélt módszerét.

A következőkben szeretnék röviden kitérni az adatvédelmi jog robbanásszerű térnyerésének gyújtópontjában lévő jogszabályra, amely jelen dolgozat témájaként szolgáló jogalapok új rendszerének bevezetéséért is egyúttal felelős.

\section{A Rendelet és nóvumai}

Az Európai Parlament és a Tanács (EU) 2016/679. számú rendelete egy hosszú adatvédelmi reform végeredményeként jött létre. Előképének tekinthető az Európai Parlament és a Tanács 95/46/EK irányelve a személyes adatok feldolgozása

\footnotetext{
${ }^{1}$ Az Európai Parlament és a Tanács (EU) 2016/679 a természetes személyeknek a személyes adatok kezelése tekintetében történő védelméről és az ilyen adatok szabad áramlásáról, valamint a 95/46/EK rendelet hatályon kívül helyezéséről (általános adatvédelmi rendelet. a továbbiakban: Rendelet vagy GDPR)
} 
vonatkozásában az egyének védelméről és az ilyen adatok szabad áramlásáról (továbbiakban: adatvédelmi irányelv), amelynek megalkotásakor még nem kifejezetten az emberi jogok átfogó védelme volt a cél, sokkal inkább a belső piac múködését korlátozó - személyes adatok továbbításával összefüggő - akadályok lebontása, vagyis a tagállamok közötti adatáramlás elősegítése. ${ }^{2}$ A GDPR, ellentétben az adatvédelmi irányelvvel, sokkal nagyobb hangsúlyt fektet a személyes adatok védelmére irányuló előírások modernizálására és fejlesztésére, bár számos az irányelvből átvett megoldást alkalmaz továbbra is. ${ }^{3}$ Legnagyobb eltérése jogforrási formájában rejlik, lévén rendeletként került megalkotásra. Ebből kifolyólag nem igényel és nem tűr átültető aktusokat a tagállamok részéről. Ettől függetlenül elmondható, hogy több mint 50 kérdésben enged kifejezetten teret a tagállami jogalkotásnak. ${ }^{4}$

2009-ben a Lisszaboni Szerződés elfogadásával vált lehetségessé az átfogó reform elindítása. A Szerződés a személyes adatok védelméhez füződő jogot alapítószerződési szinten rögzítette, így a Tanács és az Európai Parlament felhatalmazást kapott a rendes jogalkotási eljárás keretei között másodlagos jogforrások létrehozására. A jog érvényesülésén, a szabadságon és a biztonságon alapuló térségre vonatkozóan 2010 és 2014 közötti időszakban prioritásokat megállapító Stockholmi Program keretében felkérte az Európai Tanács a Bizottságot „az uniós adatvédelemi szabályozás és ezen értékelés eredményének függvényében jogalkotási és nem jogalkotási kezdeményezések benyújtására". Számos szakmai konzultációt és konferenciát követően 2012-ben terjesztette elő jogalkotási javaslatcsomagját a Bizottság, amely tartalmazta a GDPR és a bűnügyi irányelv ${ }^{5}$ megalkotására vonatkozó javaslatokat is. A rendes jogalkotási eljárásnak megfelelóen a Parlament 2014. márciusában, a Tanács a politikai nyomás ellenére valamivel később, 2015. június-októbere között fogadta el álláspontját. A társjogalkotók közti tárgyalások 2015. végére meghozták gyümölcsüket és létrejött a politikai megegyezés. A jogtechnikai és nyelvészeti felülvizsgálatokat követően 2016. áprilisában lezárult a jogalkotási eljárás. Május 24-én lépett hatályba a GDPR, de saját maga által megállapított felkészülési idő elteltével, 2018. május 25. napja óta kell alkalmazni. ${ }^{6}$

\footnotetext{
${ }^{2}$ Péterfalvi Attila - Révész Balázs - Buzás Péter (Szerk.): Magyarázat a GDPR-ról. Budapest, Wolters Kluwer Hungary, 2018. 25-26. o.

${ }^{3}$ Kis Kelemen Bence - Hohmann Balázs: A Schrems itélet hatásai az európai uniós és magyar adattovábbítási gyakorlatokra. Infokommunikációs jog, 2016/2., 64-66. o.

${ }^{4}$ Sepsi Tibor: GDPR útikalau₹ adatkezelöknek. Budapest, Wolters Kluwer Hungary, 2019. 19-20. o.

${ }^{5}$ Az Európai Parlament és a Tanács személyes adatoknak az illetékes hatóságok által a bűncselekmények megelőzése, nyomozása, felderítése, a vádeljárás lefolytatása vagy büntetőjogi szankciók végrehajtása céljából végzett kezelése tekintetében a természetes személyek védelméről és az ilyen adatok szabad áramlásáról, valamint a 2008/977/IB tanácsi kerethatározat hatályon kívül helyezéséről szóló 2016/680 irányelve

${ }^{6}$ Péterfalvi, et. al., 2018, i.m. 29-32. o.
} 
Maga a rendelet 173 preambulumbekezdésből és - XI. fejezetre osztva 99. cikkből áll. Ebből a 99. cikkből 39 jelöl az adatkezelő számára valamilyen végrehajtandó kötelezettséget, a többi 60 leíró, adminisztratív jellegủ vagy a hatóság eljárására vonatkozik. Megszövegezése nem meglepő módon rendkívül absztrakt, ennek megfelelően a rendelkezések több logikai lépést igényelnek az alkalmazásuk során. ${ }^{7}$

Elvitathatatlan, hogy számos újítást hozott a korábbi Uniós vagy hazai adatvédelmi joghoz képest. Összességében elmondható, hogy nem annyira azon változtatott, hogy mit lehet kezelni, hanem azon, hogy hogyan lehet azt megtenni. ${ }^{8}$

\section{Az adatkezelési jogalapok új rendszere}

A téma szempontjából különös jelentőséggel bíró adatkezelési jogalapok a korábbi dichotóm rendszerhez képest nagymértékű változáson mentek keresztül. Jogalap alatt azt az erkölcsileg és törvényileg helytálló hivatkozást, jogcímet értjük, amely szükséges valamely jog érvényesítéséhez. ${ }^{9}$ Nem véletlen, hogy a GDPR 6. cikkének címe - amely a lehetséges jogalapokat rögzíti - „Az adatkezelés jogszerűsége”, hiszen valamely jogalap hiányában az adatkezelés jogszerű egyáltalán nem lehet. ${ }^{10}$ Szintén fontos kiemelni a jogalapok tárgyalása előtt, hogy a jogszerűséghez az érvényes jogalap mellett egy pontosan és részletesen meghatározott adatkezelési célra is szükség van. ${ }^{11}$

A korábbi hazai szabályozás, vagyis a személyes adatok védelméról és a közérdekú adatok nyilvánosságáról szóló 1992. évi LXIII. törvény (továbbiakban: Avtv.) alapvetően kettő jogalappal múködött, a hozzájárulással és a törvényi felhatalmazással. Az információs önrendelkezési jogról és az információszabadságról szóló 2011. évi CXII. törvény (továbbiakban: Info.tv.) az Avtv. szisztémájától eltérően a magyar adatvédelmi rendszerben addig elfogadott két jogalap mellett, azokat kiegészítve bevezette az adatvédelmi irányelv 7. cikkének c) és f) pontja szerinti új jogalapokat is, a jogi kötelezettség teljesítéséhez szükséges adatkezelést, valamint az érdekmérlegelésen alapuló adatkezelést. Ezek szűk körben még, és csak átfogó garanciális szabályok mellett tették lehetővé, hogy meghatározott esetekben az érintett hozzájárulása hiányában, és a jogalkotó közhatalmi aktusa nélkül is sor kerüljön a személyes adatok kezelésére. ${ }^{12}$

Az adatvédelmi irányelv által kijelölt úton haladva a Rendelet tovább bővítette a magyar jog által ismert jogalapok körét, azokat pedig kölcsönös mellérendeltségben helyezte el anélkül, hogy bármelyiket egyik vagy másik fölé

\footnotetext{
${ }^{7}$ Sepsi, 2019, i.m. 22. o.

${ }^{8}$ U.o. 32. o.

${ }^{9}$ Péterfalvi, et. al., 2018, i.m. 111. o.

${ }^{10} \mathrm{Az}$ Európai Unió Alapjogi Ügynöksége és az Európa Tanács: Európai adatvédelmi jogi kézįikönyv. Luxembourg, Az Európai Unió kiadóhivatala, 2019. 158. o.

11 A 29. cike szerinti munkacsoport 03/2013 sqámú véleménye a célhoz kötöttségröl (WP203), 15-16. o.

12 2011. évi CXII. törvény indokolása az információs önrendelkezési jogról és az információszabadságról
} 
sorolta volna. Azt azonban fontos kiemelni, hogy bár szabadon használható bármely jogalap, egy adatkezelésnek egyszerre csak egy érvényes jogalapja lehet. Példának okáért egy szerződésben szereplő adathalmaz jogalapja csak 6. cikk b) pont szerinti szerződés teljesítése lehet, még akkor is, ha előrelátható, hogy a szerződés megszűnését követően jogi igények érvényesítése érdekében más jogalap használatával, de azonos adatkörre új adatkezelés indulhat. Tehát az adatkezelőnek nem egy bizonyos személyes adat, hanem az azzal kapcsolatos adatkezelési folyamat vonatkozásában kell megtalálnia a megfelelő jogalapot. Ezt az a tény is alátámasztja, hogy különböző célok érdekében, eltérő jogalapok alapján is lehetséges ugyanazt az adatkört kezelni (pl.: szerződésben szereplő név megegyezik a kapcsolattartáshoz használt névvel és akár a direkt marketing célú hírlevél feliratkozásban szereplő névvel). ${ }^{13} \mathrm{Az}$ alábbiakban a szükséges mértékre korlátozva, de az egyes jogalapokat külön-külön ismertetem.

\section{Az érintett hozzájárulása}

Az olyan esetekben, amikor hozzájárulás bekérése válik szükségessé, akár azért, mert jogszabály előírja. (pl.: a gazdasági reklámtörvény az e-DM levelek esetén ${ }^{14}$, Polgári Törvénykönyv (továbbiakban: Ptk.) kép és hangfelvétel készítésekor ${ }^{15}$ ) vagy az adatkezelő saját döntése szerint, mindig szigorú feltételeknek kell megfelelni ahhoz, hogy az jogszerủ adatkezelést eredményezzen. Fontos, hogy az adatkezelő mindig képes kell legyen arra, hogy a hozzájárulás megadását igazolni tudja (tehát rögzítettnek és visszakereshetőnek kell lennie), valamint azt is bizonyítania kell, hogy azt az érintett önkéntesen adta meg. Az önkéntesség vizsgálata objektív és szubjektív szempontok szerint is történik, így már nem elégséges megoldás azt egyszerúen „lenyilatkoztatni”. ${ }^{16}$ Különös súlya van az önkéntesség esetén annak bizonyításának, hogy létezett a hozzájárulásnak alternatívája, vagyis, annak, hogy az érintett választása esetén hozzá tudott volna férni ugyanahhoz a szolgáltatáshoz a hozzájárulásának megadása nélkül is. ${ }^{17}$ Szintén ebben a problémakörben szükséges megemlíteni, hogy a felek közötti jelentős egyenlőtlenség (másként megfogalmazva: alá-fölé rendeltség) súlyos következményekkel járhat az adatkezelés jogszerűségére, amit a Hatóság - támaszkodva a Munkacsoport ${ }^{18}$ megállapításaira is - a munkahelyi adatkezelések alapvető követelményeiről szóló 2016-os tájékoztatójában

\footnotetext{
${ }^{13}$ Péterfalvi, et. al., 2018. i.m. 111. o.

${ }^{14}$ 2008. évi XLVIII. törvény 6. \ (1) bekezdés

15 2013. évi V. törvény 2:48. \$

${ }^{16}$ Európai Adatvédelmi Testület: Guidelines 05/2020 on consent under Regulation 2016/ 679, Version 1.1, 2020.

7 o. https://edpb.europa.eu/sites/default/files/files/file1/edpb guidelines 202005 consent en.pdf

(2021.08.01.)

${ }^{17}$ Kulcsár Zoltán: Privacy Policy Online Services, A bozzájárulás fogalmának kiegészitése az Európai Adatvédelmi Testület 5/2020 iránymutatásában, 2020. https://www.adatvedelmirendelet.hu/uncategorized/ahozzajarulas-fogalmanak-kiegeszitese-az-europai-adatvedelmi-testulet-5-2020-iranymutatasaban/ (2021.08.01.)

18 29. szerinti munkacsoport (továbbiakban: Munkacsoport)
} 
kifejezetten ki is emelt. ${ }^{19}$ Érdekességképpen megjegyezhető, hogy a GDPR eredeti - Bizottság által javasolt - szövegverziója szerint amennyiben jelentős egyenlőtlenség áll fenn az érintett és az adatkezelő helyzete között, akkor a hozzájárulás nem teremtett volna jogalapot az adatkezelésre. ${ }^{20}$

Megjegyzendő, hogy az egyetlen jogalap, amelynél speciális tájékoztatási szabályok (különös tekintettel annak egyértelműségére ${ }^{21}$ ) vannak érvényben, továbbá a legerőteljesebb rendelkezési jogot adja az érintettnek, mivel lehetôvé teszi számára, hogy a hozzájárulását bármikor visszavonhassa, ezzel ellehetetlenítve az adatkezelési tevékenység folytatását. ${ }^{22}$

Úgy gondolom az alkalmazási nehézséget a hozzájárulásokkal kapcsolatban azok megalapozatlan és sok esetben visszaélésszerű alkalmazásának gyakorlata, valamint az azonnali törlést eredményező visszavonás joga jelenti, ebből kifolyólag a jogalap használatát a legszükségesebb esetekre érdemes korlátozni. Állításom magyarázatául először arra hívnám fel a figyelmet, hogy a GDPR előtti gyakorlat szerint a szerződésekben (pl.: munkaszerződések) található adatvédelmi rendelkezések kimerültek a „személyes adataim kezeléséhez hozzájárulok” kitételben. ${ }^{23}$ Ez nyilvánvalóan már akkor is elégtelen volt, hiszen ebból nem derült ki, hogy milyen adatokra vonatkozik a hozzájárulás, és azok milyen célokra használhatók fel, ki az adatkezelő, valamint, hogy meddig tárolhatók az adatok. A visszaélések pont ebben rejlettek, hiszen a megfogalmazásnak hála lehetetlen volt azt bizonyítani, hogy pontosan mihez történt a hozzájárulás. Az alkalmazási tárgykörök korlátlansága miatt pedig egyszerű megoldás volt mindenhez bekérni a hozzájárulást, akkor is, ha az adatok nem voltak szükségesek vagy azok egyenesen hátrányos helyzetbe hozták az érintettet. A hozzájárulási érme másik oldala, mikor a jóhiszemú adatkezelő bekéri a személyes adatok kezeléséhez a hozzájárulást, ám az érintett formál-jogi szempontból kifogástalan magatartással kéri az adatok törlését. A feleslegesen bekért hozzájárulások esetén a helyzet súlya akkor válik kézzelfoghatóvá, ha a példa kedvéért az adatok egy szerződésben vagy egy számlán szerepelnek. Utóbbi esetben egy felkészült adatkezelő még akkor is, ha eredetileg tévedésből vagy biztos, ami biztos alapon - a számla kiállításához is bekérte a hozzájárulást, védekezhetett törvényen alapuló adatkezeléssel, ezáltal a törlési kérelmet eredményesen tudta elutasítani. Azonban a szerződés esetén erre nem volt lehetôsége, hiszen a szerződési szabadsággal összhangban (eltekintve természetesen a kógens jogszabályi rendelkezésektől) általában nem normatív előírásokon alapul a

\footnotetext{
19 A Nemzeti Adatvédelmi és Információszabadság Hatóság tájékoztatója a munkahelyi adatkęzelésele alapvetó követelményeiröl (2016). 7. o.

${ }^{20}$ Szőke Gergely László: Az adatvédelem szabályozásának történeti áttekintése. Infokommunikáció és jog, 2013/3, 110. o.

${ }^{21}$ Rendelet 32. preambulumbekezdés

${ }^{22}$ Salami, Emmanuel: An Analysis of the General Data Protection Regulation (EU) 2016/679, 2017. 7 o. http://dx.doi.org/10.2139/ssm.2966210

${ }^{23}$ Bölcskei Krisztián: GDPR Kérikönyv 2.0, Új EU-s Adatvédelmi Rendelet, Info tv., GDPR Salátatörvény. Budapest, Vezinfó Kiadó, 2019. 58-59. o.
} 
szerződésben szereplő adatok kezelése. Látható, hogy ad absurdum előfordulhatott olyan eset, amikor az adatkezelő egy fennálló jogviszony vagy jogi kötelezettség teljesítéséhez szükséges adatokat törölt a hozzájárulás visszavonásának következtében.

A fentiekből kifolyólag - alapozva a hozzájárulással szemben kialakuló nemzetközi szkepticizmusra is - úgy gondolom, hogy a korábbi gyakorlattal (vagyis a jogszabályi rendelkezés hiányában a hozzájárulás automatikus bekérésével ${ }^{24}$ ) teljes mértékben szakítva, a hozzájárulásnak az utolsó opciónak kell lennie a jogalapok választásakor, illetve olyan helyzetekre kell korlátozni, amikor nincs különösebb jelentősége az adattörlési kérelem teljesítésének. Így például egy munkavállaló esetén a céges weboldal dolgozói bemutatkozó felületén közzétett adatokkal és képekkel kapcsolatban, céges rendezvényeken készült képekkel, vagy promóciós anyagokban szereplő adatokkal kapcsolatos (a Ptk. rendelkezéseit is figyelembe vevő) adatkezelések esetén használható a hozzájárulás, de egyéb esetekben más jogalap használata mutatkozik célszerűnek. Tisztában vagyok azzal az elgondolással, hogy a hozzájárulás biztosítja az érintett számára az önrendelkezési jogának legteljesebb formáját és elméletileg a lehető legkedvezőbb ránézve ennek a jogalapnak a használata. Azonban a korábbi és jelenlegi gyakorlatot is figyelembevéve a hozzájárulások önkéntessége ritkán tekinthető valósnak, a legtöbb esetben pusztán adminisztratív módon realizálódik. ${ }^{25}$

Fontosnak tartom kiemelni a hozzájárulás alkalmazásának jogszabály által megkövetelt módjával kapcsolatban, hogy a jogalkotó és a hatóság gyakorlata szerint is visszaszoruló tendenciát mutat ez a megoldás. A jogalkotási trend esetén példaként említhető a személy- és vagyonvédelmi, valamint a magánnyomozói tevékenység szabályairól szóló 2005. évi CXXXIII. törvény (Szvmt.) módosítása a 2019. évi XXXVI. törvény (un. GDPR-Salátatörvény) hatályba lépése által. A korábbi szabályozástól eltérően az elektronikus megfigyelés vonatkozásában az adatkezelő igazolható jogos érdeke vagy fennálló közérdek (tehát nincs szükség a hozzájárulásra sem) alapján határozhatja meg az elérendő célt és az ehhez szükséges adatkezelési időt. ${ }^{26} \mathrm{~A}$ hatósági gyakorlattal összefüggésben említhető a Nemzeti Adatvédelmi és Információszabadság Hatóság állásfoglalása a digitális oktatással kapcsolatban. ${ }^{27} \mathrm{E}$ szerint a COVID-19 járvány alatt megvalósított távoktatás vagy digitális oktatás során a pedagógus által gyakorlati teljesítés megtekintése céljából bekért fényképekkel vagy videófelvételekkel kapcsolatban megvalósuló adatkezelés

\footnotetext{
${ }^{24}$ Freidler Gábor: A munkaviszonnyal összefüggő adatkęzelések. In: Péterfalvi Attila (Szerk.): Adatvédelem és információszabadság a mindennapokban. Budapest, HVG-ORAC Lap- és Könyvkiadó, 2012. 289. o.

${ }^{25}$ Schermer, Bart Willem - Custers, Bart - van der Hof, Simone: The Crisis of Consent: How Stronger Legal Protection May Lead to Weaker Consent in Data Protection. Ethics and Information Technology. 2014. 7-12. o. http://dx.doi.org/10.2139/ssm.2412418

${ }^{26}$ Kulcsár Zoltán: Privacy Policy Online Services, GDPR-Salátatörvény elfogadásával kapcsolatos föbb változások. https://www.adatvedelmiszakerto.hu/2019/04/a-gdpr-salatatorveny-elfogadasaval-kapcsolatos-fobbvaltozasok/ (2021.08.01.)

${ }^{27}$ NAIH/2020/2888. számú állásfoglalás
} 
a közfeladat ellátásából fakadóan un. „kötelező” jellegú, így a Ptk. 2:48. 『 (1) bekezdése nem vonatkozik rá és nincs szükség hozzájárulás bekérésére, a jogalap pedig az adatkezelés közérdekűsége lesz. Szintén itt említhető, hogy az Európai Adatvédelmi Testület COVID-19 járvánnyal kapcsolatosan megvalósuló kontaktkutatás esetén alkalmazott online alkalmazások vonatkozásában leszögezte, hogy az adatkezelés lehet közérdekű (tehát 6 . cikk (1) bek. e) pont szerinti), függetlenül attól, hogy annak használata önkéntességen alapul. ${ }^{28}$

\section{Szerzódés teljesítése}

A GDPR 6. cikk (1) bekezdés b) pontjában meghatározott szerződés teljesítéséhez szükséges adatkezelést kettő esetben engedi használni. Egyfelől a megkötendő szerződést előkészitő lépések során, másfelől az érintettel kötött szerződés tényleges teljesítése alatt. ${ }^{29}$

Utóbbi esetben természetesen az egyik legfontosabb feltétel, hogy a szerződő fél az érintett legyen, éppen ezért nem alkalmazható szerződéses jogalap a már megszűnt szerződések alapján indított igényérvényesítések vagy a követelésátruházás esetén, ugyanis egyik esetben sincs az adatkezelő és az érintett között érvényes szerződés. Az, hogy esetlegesen volt korábban, de megszűnt vagy van érvényes szerződés, de azt az adatkezelőtől eltérő személlyel kötötték, nem jöhet számításba. Ilyenkor más jogalap alkalmazása szükséges, jelen helyzetben például mindkét esetben az f) pont szerinti jogos érdek alapján lehet az igényérvényesítési eljárásban vagy a faktorált követelésben szereplő adatokat kezelni. Lényegtelen azonban, hogy a szerződést fizikailag az érintett kötötte-e meg, elég, ha szerződő félnek minősül. Szerződés fogalma alá pedig egyaránt beletartozik az írásbeli, az elektronikus úton és a szóban kötött szerződés is, továbbá annak sincs jelentősége, hogy polgári, közigazgatási, munka- vagy egyéb jogon alapul. ${ }^{30}$ Szintén kiemelten fontos kritérium, hogy az adatok kezelése objektíve szükséges legyen a szerződés teljesítéséhez ${ }^{31}$, amely jelen esetben nem azt jelenti, hogy minden adatnak a szerződésben kell szerepelnie ${ }^{32}$.

${ }^{28}$ Európai Adatvédelmi Testület 04/2020 s\%: a COVID19-járvánnyal összefüggésben a belymeghatározó adatok és a

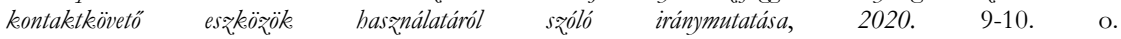
https://edpb.europa.eu/sites/default/files/files/file1/edpb guidelines 20200420 contact tracing co vid with annex hu.pdf

(2021.08.01.)

${ }^{29}$ Péterfalvi, et. al., 2018, i.m. 123-124. o.

${ }^{30}$ U.o. 124. o.

${ }^{31}$ Zuiderveen Borgesius, Frederik: Personal Data Processing for Behavioural Targeting: Which Legal Basis?, 2015.

9-10 o. https: // ssrn.com/abstract $=2662008$

(2021.08.01.)

32 Európai Adatvédelmi Testület: 2/2019 iránymutatás a személyes adatoknak az általános adatvédelmi rendelet 6. cikee (1) bekeqdésének. b) pontja szerinti kezzeléséröl az érintettek részére nyújtott online szolgáltatások összefüggésében, 2019. 8. o. https://edpb.europa.eu/sites/default/files/files/file1/edpb guidelines-art 6-1-badopted after public consultation hu.pdf (2021.08.01.) 
A hozzájárulás jogalapjánál említett problémák a szerződéses jogalap esetén nem merülnek fel, így véleményem szerint sokkal kiszámíthatóbb adatkezelést eredményez. Ez esetben nem lehetséges meghatározhatatlan adatkör kezelését hozzájárulás alapján elkezdeni, csak azt, ami a szerződés megkötéséhez, teljesítéséhez és megszüntetéséhez szükséges. Ehhez egyébiránt nincs is szükség pontosabb megfogalmazásra, hiszen a polgári jog vagy a munkajog által jól azonosíthatóvá válik a szóban forgó adatkör. Fontos szempont, hogy az érintett már nem képes önhatalmúlag töröltetni az adatokat, mivel az adatkezelés elválaszthatatlanul összekötődött a szerződéses jogviszonnyal, tehát amíg létezik érvényes szerződés a felek között az adatkezelés is jogszerủen folytatható. Ennek egyébként a fordítottja is igaz lehet, ugyanis a tisztességesség elvéből fakadóan érvénytelen - akár semmis, akár megtámadható - szerződés alapján adatokat jogszerúen kezelni nem lehet. ${ }^{33}$

A szerződéses jogalap másik esete, amikor az adatkezelés a szerződéskötést megelőző, az érintett kérésére történő lépések megtételéhez szükséges. Ez az az átmeneti időszak, amikor még nincs érvényes szerződés, de a felek a szerződéskötési akaratukat kinyilvánították egymás felé és olyan adatok kezelésére van szükség, amelyek nélkül nem lehet később megkötni a szerződést. Ez egy konkrét (személyre szabott) árajánlat kérésétől a szerződéskötést megelőző tárgyalásokon keresztül, a szerződés megkötéséig tarthat. ${ }^{34} \mathrm{~A}$ jogalap használhatóságának legkorábbi időpontja az érdeklődés kifejezése is lehetne, de álláspontom szerint ez esetben (az Európai Adatvédelmi Testület állásfoglalásában szereplő esetkört megszorítóan értelmezve ${ }^{35}$ ) a pillanat olyan távoli, hogy a legcsekélyebb bizonyossággal sem jelenthető ki, hogy ez a szándék valódi-e. Az üzleti életben egyébként nem ritka, hogy a lehetséges vevő számos lehetőséget körbejár mielőtt döntését meghozná, ilyen esetekben pedig bizonyosan nem több szerződést kíván megkötni, hanem csak egyet. Így az érdeklődés szakaszában rekedt állapotot nem tartom szerződéskötést megelőző lépésnek. Tekintve, hogy a puszta válaszadás mellett az adatkezelőnek érdeksérelmet nem okoz az adatok esetleges törlése, egy vevő/megrendelő érdeklődésében szereplő adatait hozzájárulásuk alapján kezelném.

\section{Jogi kötelezettség teljesítése}

A c) pontban olvasható jogalap esetén az adatkezelés az adatkezelőre vonatkozó jogi kötelezettség teljesítéséhez szükséges. Számos jogszabályról lehet szó, amelyek személyes adatok kezelését írják elő (i), követelik meg (ii) vagy teszik lehetővé (iii). ${ }^{36}$

Első esetben a jogszabály konkrétan előírja milyen adatokkal, milyen célból és milyen időtartamban kell kezelnie az adatkezelőnek a személyes adatokat. Az adminisztratív terhen túl, adatvédelmi szempontból ez egy könnyú helyzet, hiszen

\footnotetext{
${ }^{33}$ Uo. 124. o.

${ }^{34}$ Uo. 125-126. o.

${ }^{35}$ Európai Adatvédelmi Testület: 2/2019 iránymutatás, i.m. 14. o.

${ }^{36}$ Az Európai Unió Alapjogi Ügynöksége és az Európa Tanács, 2019, i.m. 168-169. o.
} 
elsődlegesen a jogalkotónak kell vizsgálnia az adatkezelés jogszerűségét. ${ }^{37}$ Számtalan ilyen konkrét rendelkezés található például a gyermekvédelmi törvényben ${ }^{38}$ vagy az egészségügyi és a hozzájuk kapcsolódó személyes adatok kezeléséről és védelméről szóló törvényben. ${ }^{39}$

Második eset, amikor a jogszabály olyan jogi kötelezettséget ír elő, amelyet csak nyilvánvalóan személyes adatok kezelésével lehet betartani, azonban az Info.tv. 5. (3) bekezdésében megkövetelt részletességgel nem írja le az adatkezelés körülményeit. Ilyen esetekben az adatkezelő (jogállásától függően) döntésén múlhat, hogy a szükségesség és arányosság vizsgálatával vagy érdekmérlegelési teszt útján fogja a törvény előírásainak betartásához füződő közérdeket, illetve jogos érdeket bizonyítani, vagy úgy ítéli meg, hogy eléggé egyértelmú maga a kötelezettség, és annak teljesítéséhez szükséges adatkezelés minden lényeges körülménye is. Utóbbi esetben megteheti, hogy továbbra is jogi kötelezettség teljesítése érdekében folytatja az adatok kezelését, de annak kockázatával kell ezt tennie, hogy a Hatóság esetlegesen egyet nem értését fogja kifejezni döntésével kapcsolatban. Erre az esetre példaként említhető a munkaidő-nyilvántartási vagy a számviteli bizonylat megőrzési kötelezettség. ${ }^{40}$

Harmadik esetben a jogszabály mindössze felhatalmazást ad az adatok kezelésére ${ }^{41}$, amely a gyakorlatban sok mindent jelenthet, hiszen a legtöbb jogszerű életviszony levezethető valamilyen jogszabályi felhatalmazásból vagy épp tiltásból. Ettől függetlenül egyértelműen helytelen ilyen esetekben jogi kötelezettség teljesítésére alapítani az adatkezelést.

Végezetül fontos megjegyezni, hogy jogi kötelezettségnek tekinthető az az eset is, amikor bíróság vagy hatóság eljárásjogi jogszabályra történő hivatkozás kíséretében, írásban adatok átadását kéri. ${ }^{42}$

\section{Létfontosságú érdek}

Előfordulhatnak olyan körülmények, amelyekben az adatkezelés az érintett vagy egy másik természetes személy létfontosságú érdekeinek védelme miatt szükséges és más jogalap a szóban forgó adatokhoz nem áll rendelkezésre ${ }^{43}$. Az ilyen helyzetekre felkészülve került be a Rendeletbe a 6. cikk d) pontja. Az élethelyzetek sokfélék lehetnek, az esetek többségében az élet, testi épség és egészség védelme érdekében kerülhet sor az alkalmazására, de álláspontom szerint az érintett nyilvánvaló érdekében álló, vagyoni kár bekövetkezésekor vagy bekövetkezési esélyének felmerülésekor is használhatónak kell lennie.

\footnotetext{
${ }^{37}$ Uo. 169 o.

38 1997. évi XXXI. törvény 134. \-136/B. \

39 1997. évi XLVII. törvény az egészségügyi és a hozzájuk kapcsolódó személyes adatok kezeléséről és védelméről

40 Péterfalvi, et. al., 2018. i.m. 127. o.

${ }^{41}$ Uo. 127 o.

42 Uo. 128 o.

43 Az Európai Unió Alapjogi Ügynöksége és az Európa Tanács, 2019, i.m. 169-170. o.
} 
Fontos kitétel a jogalap alkalmazásával kapcsolatban, hogy az emberi élet védelme esetén sem szolgálhat egészségügyi adat kezelésének alapjául (arra a GDPR 9. cikk (2) bekezdése vonatkozik). Az érintett létfontosságú érdeke szerint tehát az allergia fajtáját nem, de az értesítendő hozzátartozó elérhetôségét lehet kezelni. ${ }^{44}$

\section{Közérdekü feladat ellátása, közhatalmi jogosítvány gyakorlása}

A 6. cikk e) pontban került meghatározásra azon eset, amikor az adatkezelés közérdekű vagy az adatkezelőre ruházott közhatalmi jogosítvány gyakorlásának keretében végzett feladat végrehajtásához szükséges. A rendelkezés két fordulatra bontható, közérdekű adatkezelésre és közhatalom gyakorlásával kapcsolatos adatkezelésre.

A Rendelet magyar fordításában szereplő közérdekủ feladat meghatározásához a gyakorlat szerint a magyar közfeladat fogalma hívható segítségül, így közfeladatot lát el minden az állam- és önkormányzati igazgatáshoz tartozó szerv (i), valamint a jogszabály által létrehozott, jogszabályban meghatározott feladatkörrel rendelkező szerv vagy személy (ii). A közhatalmat gyakorló szervek és a közfeladatot ellátó szervek között láthatólag átfedés van, hiszen a közhatalom feltételezi a közfeladat ellátására irányuló feladatok meglétét. ${ }^{45}$ Fontos azt is látni azonban, hogy nem minden közfeladatot ellátó szerv gyakorolhat közhatalmat (pl.: közoktatásban résztvevő intézmények), de mindkettő típusú szerv feladatait uniós vagy tagállami jog kell, hogy meghatározza. Utóbbi kitétel miatt ezen jogalap általában az un. „kötelező adatkezelések” kategóriájába sorolják", bár számomra sok tekintetben hasonlóságokat mutat a következő pontban taglalt jogos érdek jogalapjával. Összehasonlításuk szempontjából fontos tényező egymáshoz viszonyitott kizártságuk, hiszen a GDPR egyfelől explicite megtiltja az érdekmérlegelés használatát közhatalmi szervek számára, ${ }^{47}$ míg a közfeladat hiánya (legtöbb esetben) lehetetlenné teszi a magánszféra számára ennek a jogalapnak az alkalmazását. ${ }^{48}$ Ugyan nem egyértelmú, hogy ez csak a közhatalmi szervekre vonatkozhat vagy a közfeladatot ellátó szervekre is (a Rendelet nem említi utóbbi szerveket csak az adatkezelés közérdekűségét). Ettől függetlenül a gyakorlat minden e) pont alá tartozó adatkezelő számára használhatatlannak tartja az f) pontot. Előbbi kijelentésemet egyértelmúen alátámasztja - többek között - a NAIH 2020. március 10. napján kiadott állásfoglalása a COVID-19 járvánnyal kapcsolatos adatkezelések vonatkozásában. A Hatóság a megbetegedések megelőzése érdekében végzett adatgyújtések jogalapjával kapcsolatosan a következő́t mondta: „A fent megadott

\footnotetext{
${ }^{44}$ Péterfalvi, et. al., 2018, i.m. 128 o.

${ }^{45}$ Uo. 129 o.

${ }^{46}$ Uo. 129 o.

${ }^{47}$ Rendelet 6. cikk (1) bekezdés utolsó fordulata

48 Information Comissioner's Office: Lawful basis for processing, Public Task. http://ico.org.uk/fororganisations/guide-to-data-protection/guide-to-the-general-data-protection-regulation-gdpr/lawfulbasis-for-processing/public-task/ (2021.08.01.)
} 
adatok kezelésének. [kérdöivben szereplö adatok] jogalapjául ebben az esetben a GDPR 6. cikek (1) bekezqués f) pontja szerinti jogalap, illetve közfeladatot ellátó, illetve közhatalmat gyakorló szervezetek adatkezelései esetében a 6. cikek (1) bekezqués e) pontja szolgálhat, tekintettel alapfeladatuk zavartalan ellátásának szülkségességére." $49 \mathrm{Az}$ idézet jól tömöríti álláspontomat a két jogalap múködésének hasonlóságáról. Véleményem szerint ugyanarra az estkörre szánták őket alkalmazni, de egyiket a közszféra, míg másikat a versenyszféra szereplői számára. E kettó között a legnagyobb különbséget az e) pont szerinti jogalap törvény általi meghatározottsága és az f) pontban rögzített érdekmérlegelési teszt elvégzésének kötelezettsége jelenti. A jogos érdekről a következő alpontban részletesen lesz szó, a közérdekű adatkezeléssel kapcsolatban azonban megjegyzendő, hogy a közszféra szerveinek általában minden alapfeladata visszavezethető valamilyen jogszabályi rendelkezésre (ez teszi közfeladattá), így az alkalmazása - jogszerű múködést feltételezve - a jogos érdek mintájára, de a kötelező teszt elvégzésének kötelezettsége nélkül tud végbe menni. Egyébiránt érthető is, hogy enyhébb kötelezettséget ír elő az amúgyis rendkívül részletesen szabályozott közszféra számára a Rendelet, mint a piaci alapon múködő, döntési autonómiáját megtartó gazdasági szereplők számára.

Fontos végezetül azt is megjegyezni, hogy a közhatalmat gyakorló, illetve közfeladatot ellátó szervek tevékenységével összefüggésben végzett adatkezelésekkel kapcsolatban a Hatóság 2018. évi beszámolójában kiemelte, hogy ezen szervek tekintetében mind a közjogi, mind a magánjogi jogviszonyok esetén az e) pont szerinti jogalap „mintegy magába olvasztja, elnyeli a további adatkezelési jogalapokat”. Ezzel a kijelentéssel kapcsolatban a gyakorlat több különböző, egymással akár szöges ellentétben lévő álláspontot is magáévá tett az elmúlt években, azonban jelenlegi - a hatósági szándékhoz talán legközelebb álló - érvelés szerint ezzel a Hatóság egy lehetséges értelmezést kívánt mindössze bemutatni és nem volt célja kizárni az alkalmazási körből minden egyéb jogalapot. ${ }^{50}$

\section{Az érdekmérlegelés jogalapja}

A már hivatkozott 6 . cikk f) pont alatt olvasható a röviden érdekmérlegelés vagy jogos érdekként nevezett jogalap, amely akkor használható, ha az adatkezelés az adatkezelő vagy egy harmadik fél jogos érdekeinek érvényesítéséhez szükséges. Alkalmazási korlátját jelenti, ha előbbi érdekekkel szemben elsőbbséget élveznek az érintett olyan érdekei vagy alapvető jogai és szabadságai, amelyek a személyes adatok védelmét teszik szükségessé. ${ }^{51} \mathrm{~A}$ jogalappal kapcsolatban okkal merülhet fel a kérdés, hogy pontosan mi tartozhat a hivatkozható érdekek közé. Fontos tisztázni, hogy az érdek fogalma szorosan kapcsolódik az adatkezelés céljához, azonban azzal nem azonos. A Munkacsoport megfogalmazása szerint a cél az a különös ok, amely

\footnotetext{
${ }^{49} \mathrm{NAIH} / 2020 / 2586$. állásfoglalás

${ }^{50}$ A Nemzeti Adatvédelmi és Információszabadság Hatóság Beszámolója a 2018. évi tevékenységéröl (B/4542). Budapest, Nemzeti Adatvédelmi és Információszabadság Hatóság, 2019. 36. o.

${ }^{51}$ Az Európai Unió Alapjogi Ügynöksége és az Európa Tanács, 2019, i.m. 172-173. o.
} 
miatt az adatot kezelik, vagyis ez az adatkezelés célja és szándéka. Az érdek azonban ennél egy tágabb fogalom, vagyis egy olyan érdek, amellyel az adatkezelő rendelkezik az adatkezelésben, illetve az az előny, amelyet az adatkezelő származtat - vagy a társadalom származtathat - az adatkezelésból. ${ }^{52}$

A jogalap lényege kötetlen használhatóságában rejlik, kvázi szubszidiárius jogalapnak is nevezhetnénk, mivel, ha semmilyen másik jogalap sem alkalmazható, - nincs szerződés, sem jogi kötelezettség, a hozzájárulás önkéntessége megkérdőjelezhető, a tevékenység nem közfeladat ellátására irányul és az érintett sincs életveszélyben - de az adat kezelésére feltétlenül szükség van, akkor egy pozitív végeredménnyel záródó érdekmérlegelési teszt folytán a tevékenység folytatható lesz. Különösen nagy hangsúlyt kell fektetni ilyen esetekben az említett tesztre, amelyben alaposan körül kell járni az adatkezelés körülményeit, fel kell tárni annak okait, várható következményeit és az érintettre gyakorolt hatásait, továbbá igazolni kell azt is, hogy az adatkezelés a Rendelet - egyéb jogszabályok - előírásainak és az adatkezelő adatbiztonsági követelményeinek megfelelően történik. A tesztben feltétlenül ki kell térni a tervezett adatkezelés szükségességére és hatásainak arányosságára (un. szükségesség-arányosság vizsgálata), a jogos érdek fennállásának igazolására és az érintett érdekeinek vizsgálatára. Végeredményben annak bizonyítását kell dokumentáltan lefolytatni, hogy az adatkezelőnek a szóban forgó adatok kezeléséhez füződő érdeke elsőbbséget élvez az érintett érdekeivel, jogaival és szabadságaival szemben (fordítva megfogalmazva azt kell bizonyítani, hogy az érintettnek nincs olyan érdeke, amely elsőbbséget élvezne az adat kezelőjével szemben). Egy ilyen érdekmérlegelési tesztnek tartalmi szempontból csak az adatkezelő képzelete, bátorsága, valamint a jogszerű, tisztességes és átlátható adatkezelés elvei szabnak határt. Annyi bizonyos, hogy az érdeknek legalább törvényesnek, létezőnek és egyértelműnek kell lennie. ${ }^{53}$

Jogos érdekkel szokás tipikusan indokolni a munkáltató által végzett mindenfajta munkavállalókat célzó ellenőrzést, jogi igények érvényesítését hivatalos vagy informális eljárások keretében ${ }^{54}$ valamint a kapcsolattartásra szolgáló adatok kezelését is. Visszautalva az 5. pont alatti párhuzamra az e) és f) pont jogalapjai között itt hívnám fel a figyelmet a GDPR 21. cikkében rögzített érintetti jogra, vagyis a tiltakozáshoz való jogra. Ezzel a joggal az érintett korlátozott esetekben, kiemelten jogos érdeken vagy közhatalmon/közérdeken alapuló adatkezelések esetén élhet, újabb erőteljes hasonlóságot létrehozva e két jogalap között. A jog gyakorlása mindkét esetben ugyanazt eredményezi, az adatok kezelését korlátozni kell, a tiltakozást ki kell vizsgálni. Az érdek fennállása esetén, az igazolására szolgáló dokumentáció átadásával tudja az adatkezelő elutasítani a kérelmet. Alternatív módon az érdek hiányának megállapításakor - a kérelemnek helyt adva - az

52 A 29. cikek sžerinti munkacsoport 06/2014 számú véleménye az adatkeželój jogszerü érdekeinek. fogalmáról (WP217), 25. o.

${ }^{53}$ Péterfalvi, et. al., 2018, i.m. 132. o.

${ }^{54}$ Bölcskei, 2019, im. 167-180. o. 
adatkezelő fel kell hagyjon az adatkezeléssel, az adatok egyidejű törlése mellett. Az előző állításom úgy vélem igaz mind a jogos érdekre, mind pedig a közérdekre (együttesen kényszerítő erejű jogos oknak is nevezhetők) is, annyi eltéréssel, hogy az f) pont szerinti jogalap esetén a kérelemre elküldött válaszban szerepelnie kell az érdekmérlegelési tesztnek, e) pont esetén ilyen konkrét elvárás nincs. Ugyanez a logika fedezhető fel a GDPR 21. cikkének szószerinti megfogalmazásában: "[tiltakozás esetén] az adatkezelö a személyes adatokat nem kezelheti tovább, kivéve, ha az adatkezelö bizonyitja, hogy az adatkezzelést olyan kényszerito" erejü jogos okok indokolják, amelyek elsöbbséget élveznek az érintett érdekeivel, jogaival és szabadságaival szemben, vagy amelyek jogi igények elóterjesztéséhez, érvényesitéséhez vagy védelméhez kapcsolódnak".

\section{Különleges adatok kezelésére vonatkozó speciális szabályok}

A Rendelet 9. cikk (2) bekezdése állapítja meg azokat a többletfeltételeket, amelyeknek - a fentiekben ismertetett valamely jogalap megléte mellett - szintén meg kell felelnie a különleges adatkategóriákat érintő adatkezeléseknek. Ugyanezen cikk (1) bekezdése általános tilalmat állít fel a különleges adatok kezelésével kapcsolatban, így az említett többletfeltételek nem minősülnek önálló jogalapoknak, inkább kivételeket határoznak meg a tiltás alól. A különleges adatkategóriákkal kapcsolatos megkülönböztetett eljárás szükségességét azok általánosságban érzékenyebbnek ítélt jellege indokolja, amelyből adódóan nagyobb valószínűséggel fordulhatnak elő visszafordíthatatlan és hosszútávú károk az adat alanyának vonatkozásában. ${ }^{55}$

A (2) bekezdés a)-j) pontjai közül kiemelendő az a), amely az érintett kifejezett hozzájárulását jelöli, a b), amely középpontjában a munkajogi tárgyú szabályokat és szociális intézkedéseket tartalmazó jogszabályok állnak, a c), amely az érintett létfontosságú érdekét jelöli, de eltérően a 6. cikk d) pontjától vonatkozhat egészségügyi adatra, feltétele pedig, hogy az érintett a hozzájárulást ne legyen képes megadni, valamint a h) pont, amely egyebek mellett lehetőséget ad a munkavállaló munkavégzési képességének felmérése céljából végzett orvosi vizsgálatokra. ${ }^{56}$

\section{Jogalapválasztás elméleti folyamata}

Az előbbiek alapján megállapítható, hogy az érvényes jogalap megtalálása és használata nem egy sablonok alapján végezhető, automatizált múvelet. Annál is inkább, mert az eset bármely körülménye képes lehet a választás befolyásolására, az adatkezelési tevékenység előrehaladtával pedig elképzelhető, hogy más jogalap alkalmazása válik szükségessé.

A jogalap megválasztása előtt minden esetben az adatkezelési folyamat azonosítására van szükség, tisztában kell lenni annak részleteivel, különösen a

${ }^{55}$ Emberi Jogok Európai Bírósága, S. és Marper kontra Egyesült Királyság [Nagykamara], 30562/04. és 30566/04. sz. ügyek, 2008.

${ }^{56}$ Péterfalvi, et. al. 2018, i.m. 140-145. o. 
kitűzött adatkezelési céllal és a rá vonatkozó esetleges jogszabályokkal. Egyúttal ki kell tudni zárni azt, hogy az adatkezelés valamely jogszerűségi feltételbe (alapelvbe) ütközzön. Ha mindez megtörtént célszerűségi szempontól érdemes megvizsgálni az adatkezelést. Ebben az esetben arra a kérdésre kell keresni a választ, hogy melyik jogalap illene az adott helyzetre és, hogy a használata esetén milyen következmények várhatók. Figyelemmel kell lenni - az adatkezelő számára különösen fontos „stabilitásra” és „kiszámíthatóságra”, valamint a megvalósítás „árára”, vagyis a jogalap használatából eredő költségekre és többlet munkateherre. Saját álláspontom szerint - egy magánszektorban múködő adatkezelő számára - a vizsgálat célszerú lépései a következők (a lépések meghatározásakor figyelembe vettem a brit adatvédelmi hatóságnak a megfelelő jogalap kiválasztására szánt interaktív eszköze által tett javaslatait $\left.{ }^{57}\right)$ :

$\rightarrow$ 1. lépés: vonatkozó jogi kötelezettségek vizsgálata (6. cikk c) pont);

Egy kellően pontos jogszabályi előírás esetén kevés teendóje marad az adatkezelőnek, így egyszerűen alkalmazható jogalap. Egyébként jogi kötelezettség megléte ki is zár minden más jogalapot így feltétlenül érdemes ennek vizsgálatával kezdeni. Rendkívül fontos azonban, hogy a nem kifejezett kötelezettségek esetén amelyek az Info.tv. 5.\$ (3) bekezdésének nem felelnek meg - nem alkalmazható a c) pont szerinti jogalap, ilyenkor más jogalap alkalmazása szükséges.

$\rightarrow$ 2. lépés: szerződéskötés lehetőségének vizsgálata (6. cikk b) pont);

Ha nincs jogszabályi előírás, de a felek egyébként is szándékoztak szerződést kötni, akkor a döntés magától értetődő, érvényes szerződés esetén ezt a jogalapot kell használni. ${ }^{58}$ Azonban létezhetnek olyan esetek, amikor a korábbi gyakorlat nem tette szükségessé szerződés megkötését, azonban azt nem is zárta ki. A szerződési szabadság elvéből eredően mindig érdemes mérlegelni, hogy lehetséges-e érvényes szerződésben rögzíteni az életviszonyt.

$\rightarrow$ 3. lépés: érdekmérlegelés elvégezhetőségének vizsgálata (6. cikk f) pont); Azokban az esetekben, amikor nincs vonatkozó jogszabály vagy a rendelkezés túl általános (lásd: 3. pont), a szerződéskötés pedig az élethelyzetre értelmezhetetlen, az érdekmérlegelési teszt elvégzése merülhet fel lehetőségként. Ilyenkor alaposan át kell gondolni az adatkezelési tevékenységet és egy olyan érvrendszert kell felépíteni, ami magas bizonyossággal elfogadható lesz a Hatóság számára, egy esetleges vizsgálat során. Természetesen magasabb a bírság kockázat és a munkateher is az előbbiekhez képest, de a jogalap ettől függetlenül kiválóan alkalmazható egy megfontolt adatkezelő gyakorlatában.

$\rightarrow$ 4. lépés: hozzájárulások bekérésének vizsgálata (6. cikk a) pont);

Ha semmi sem megvalósítható a fenti lehetőségek közül, nincs jogszabályi felhatalmazás vagy épp ellenkezőleg jogszabály írja elő a hozzájárulás használatát

57 Information Comissioner's Office: Lanful basis interactive guidance tool. http://ico.org.uk/fororganisations/gdpr-resources/lawful-basis-interactive-guidance-tool/ (2021.08.01.)

${ }^{58}$ Európai Adatvédelmi Testület: 2/2019 iránymutatás, i.m. 8. o. 
(akár kifejezetten vagy más jogalapok kizárásával), akkor nem maradt más, mint annak alkalmazása. Ilyenkor hozzájárulási nyilvántartást kell elkezdeni vezetni, az érintetteket egyenként kell nyilatkozattételre kérni (annak lehetőségével, hogy megtagadhatják azt), a dokumentációt meg kell ôrizni és arra is fel kell készíteni a mechanizmust, hogy bármely érintett bármikor visszavonhatja az adott hozzájárulását. A jogalap alkalmazása előtt érdemes alaposan áttekinteni az adatkezelési folyamat technikai részleteit is, hiszen a hozzájárulás megadásának módjának is nagy jelentősége van. Fontos, hogy olyan aktív magatartáshoz kell kapcsolódjon, ami nem téveszthető össze más - a hozzájárulás megadására nem irányuló - cselekménnyel.59 Véleményem szerint az adatkezelő szempontjából kardinális jelentőséggel bíró adatkezelési folyamatot hiba hozzájárulásra alapítani. Ez alól a különleges adatok szükségszerű kezelése jelenthet egyedül kivételt. ${ }^{60}$

\section{Következtetések, összegzés}

Szándékom szerint tanulmányomban áttekintésre kerültek a GDPR és az általa bevezetett új jogalapok legfontosabb jellemzői, valamint a jogalapválasztás egy lehetséges módszertanának meghatározására is kísérletet tettem.

Összegezve az általam legfontosabb megállapításokat, fontos mindenekelőtt kiemelni, hogy a GDPR a potenciálisan alkalmazható jogalapok körét tovább bővítette. Ebből következtethetünk arra, hogy a jogalkotó döntésének hátterében az a jogpolitikai célzat húzódhat meg, amely szerint a jogalapok lehető legszélesebb köréből érdemes választania az adatkezelőnek annak érdekében, hogy az adatkezelési folyamatokhoz leginkább adekvátat tudja alkalmazni. Ennek a fontossága annál is inkább kiemelkedő, hiszen az eltérő jogalapok eltérő - de mindazonáltal jelentős - hatással vannak az érintetti jogok gyakorlására is. A jelentőséget jól szemlélteti, hogy amíg a hozzájárulás esetén annak visszavonása gyakorlatilag a törlési kérelemmel azonos (itt vizsgálni már csak a jogalap helyességét, illetve egyéb jogalap alkalmazhatóságát lehet), addig a jogos érdeken vagy közérdeken alapuló adatkezeléssel szembeni tiltakozásnak lehet helye, ami azonban korántsem azonos az adatok érdemi vizsgálatot nélkülöző törlésével. Látható továbbá az is, hogy például b) vagy c) pont esetében egyáltalán nincs „dedikált” érintetti jog, vagyis ezekben az esetekben az érintett mindössze általában élhet az adatkezeléssel szembeni panasz lehetőségével.

A rendelkezésre álló jogalapok közül - meglátásom szerint - a legtöbb élethelyzetre a b), c) és f)/e) pont alatti jogalapok alkalmazhatók, ahol az e) és f) pontok természetesen kölcsönösen kizárják egymást. Szintén említésre érdemes,

\footnotetext{
${ }^{59}$ Kulcsár Zoltán: Privacy Policy Online Services, Összefoglaló az adatvédelmi tisztviselók 2019. évi konferenciájáról (3. rész), 2020. https://www.adatvedelmirendelet.hu/uncategorized/osszefoglalo-az-adatvedelmitisztviselok-2019-evi-konferenciajarol-3-resz/ (2021.08.01.)

${ }^{60}$ A 29. cikek szerinti munkacsoport Európai Adatvédelmi Testület által jóváhagyott iránymutatása az. (EU) 2016/679 rendelet szerinti hozzájárulásról (WP259), 19. o.
} 
hogy a b) pont az egyik legtöbbször alkalmazott jogalappá nőtte ki magát, és véleményem szerint ez a tendencia a jövőben tovább fog erősödni.

Ahogy a jogalapválasztás elméleti folyamatánál is levezettem az a) pont szerinti hozzájárulás alkalmazása mind az érintett mind az adatkezelô számára nehezen alkalmazható a jelenlegi rendszerben, ahol a legtöbb esetre megfelelő alternatívát kínál a többi jogalap valamelyike. Ettől függetlenül megnyugtató azt látni, hogy mind a jogalkotói, mind a hatósági trendek szerint kikopni, de legalábbis visszaszorulni látszik a teljes hazai jogrendből, a jogszabály által megkövetelt hozzájárulás-kérési kötelezettség. 